\title{
Impact of the regional development specifics on the system of circular economy assessment
}

\author{
Olga Guman ${ }^{1}$, and Ekaterina Wegner-Kozlova ${ }^{2,3, *}$ \\ ${ }^{1}$ Ural State Mining University, Kuibyshev st., 30, 620144 Ekaterinburg, Russia \\ ${ }^{2}$ Institute of Economics The Ural Branch of Russian Academy of Sciences, Moscow str., 29, 620014 \\ Ekaterinburg, Russia \\ ${ }^{3}$ Ural Federal University named after the first President of Russia B.N. Yeltsin, Lenin str., 13B, \\ 620014 Ekaterinburg, Russia
}

\begin{abstract}
A circular economy (CE) is a sustainable development initiative aimed at reducing the linearity of social production and consumption systems. The degradation of environmental systems is quite an acute issue nowadays. The negative impact on the environment has a harmful effect even on economic indicators, as it reduces the quality of natural and human resources. At the same time, the country's ability to compete in global markets directly depends on the development of high-tech industries, which does not consider the task of maintaining environmental stability to be of paramount importance. At first glance, the task of reconciling the economic and environmental needs of society seems to be contradictory, but it requires coordinated actions in all spheres of life and constructive repositioning towards norms of sustainable development of social, economic and environmental institutions. This determines that studying the aspects of the socio-economic system transition to a circular type of development is essential. The CE offers special opportunities for industrial regions: being the basis for competitiveness they are leading in the environmental system degradation. This study focuses on the analysis of the region's ecological and industrial space and attempts to identify indicators that help integrate regional historical and economic specifics into the $\mathrm{CE}$ assessment.
\end{abstract}

\section{Introduction}

The ecosystem degradation caused by production activities led to the need for society to move towards sustainable development. This means reviewing the essential conditions and principles of environmental and economic interaction and nature management. At the same time, the national economy's ability to compete in global markets directly depends on the development of high-tech industries, which does not consider the task of maintaining environmental stability to be of paramount importance. Being contradictory at the first glance, the task of reconciling economic and environmental needs of society has found its possible solution in the concept of the circular economy $(\mathrm{CE})$.

\footnotetext{
${ }^{*}$ Corresponding author: katya.human@mail.ru
} 
The circular economy is a sustainable development initiative aimed at reducing the linearity of social production and consumption systems. The $\mathrm{CE}$ encourages the development of high-cost material cycles in tandem with more traditional processing and develops systematic approaches to cooperation between producers, consumers and other public actors in the field of sustainable development[1]. The CE describes an economic system based on business models that replace the "end-of-life" concept with reducing, reusing, recycling material flows in production, distribution or consumption processes. Achieving sustainable development implies creating a quality environment, economic prosperity and social justice for the benefit of present and future generations [2].

The switchover of the socio-economic system to a circular type of development implies coordinated actions in all spheres of life and meaningful refocusing on norms of sustainable development of social, economic and environmental institutions.

\section{Materials and Methods}

The global economic development trends prove that the progress of high-tech industries remains the crucial factor for competitiveness in the world markets. The urgent need to preserve national economy's marketability makes the country actively shift towards a circular model, which allows for a longer period preserving the practical value of resources and materials, minimizing waste generation and achieving sustainable, resource-efficient and competitive development. Besides, the global community's stricter requirements for meeting environmental standards are becoming a driver of competition.

The interest of countries in the development of the $\mathrm{CE}$ is realized in the context of legal and regulatory support of this process. In 2002, Japan has adopted the Basic Law for Establishing the Recycling-based Society. China became the first country to mention the $\mathrm{CE}$ in a normative act after passing the Circular Economy Promotion Law in 2009. Germany was one of the first states to implement a dual system of waste collection and laws on closed material cycle and waste management. In Denmark, efforts were focused on product design, changing business models and design strategies. In 2015, the European Commission facilitated the release of a European package of documents that supported the implementation of $\mathrm{CE}$ good practices [3]. The introduction of the $\mathrm{CE}$ enables countries to transform their economies by creating job opportunities and providing sustainable competitive benefits.

The CE content is based on the findings of several scientific studies. The concept combines ideas and conclusions developed within the framework of environmental economics, industrial ecology, green economy, blue economy, cradle-to-cradle design (Table 1).

Table 1. Approaches and studies reflected in the concept of the circular economy

\begin{tabular}{|c|c|}
\hline $\begin{array}{c}\text { The name of the } \\
\text { concept }\end{array}$ & General description of the concept \\
\hline $\begin{array}{c}\text { Sustainable } \\
\text { development }\end{array}$ & $\begin{array}{l}\text { Sustainable development means meeting the needs of the current generation } \\
\text { without depriving future generations of this option. Sustainable development } \\
\text { combines the elaboration and successful implementation of advanced technologies } \\
\text { and their organic integration into the social and economic sphere together with } \\
\text { environmental protection as an integral part of the development process. }\end{array}$ \\
\hline Green economy & $\begin{array}{l}\text { It was seen in the context of sustainable development as a type of economy that } \\
\text { "should contribute to sustainable economic growth, improve human well-being } \\
\text { and create new employment opportunities while maintaining healthy functioning } \\
\text { of the Earth's ecosystems" [4]. The OECD developed and introduced the concept } \\
\text { of green growth, defining it as maximizing economic growth and progress without } \\
\text { affecting the quantity and quality of natural assets and leveraging the growth } \\
\text { potential that occurs during the shift to the green economy. Green growth is a GDP } \\
\text { increase that focuses on green growth drivers. }\end{array}$ \\
\hline
\end{tabular}


Continuation of Table 1. Approaches and studies reflected in the concept of the circular economy

\begin{tabular}{|c|c|}
\hline Blue economy & $\begin{array}{c}\text { In this concept lies the idea that the waste of one product becomes the raw material } \\
\text { that brings new financial flow [5]. An economy that encourages the switch from a } \\
\text { commodity economy to an economy of systems [6]. }\end{array}$ \\
\hline Cradle-to-cradle & $\begin{array}{r}\text { The concept of waste-free production based on the principles of regenerative } \\
\text { design [7]. The basic principle of this model assumes that the consumer does not } \\
\text { pay for the product itself, but for its use. It will be the manufacturer himself who } \\
\text { will maintain and dispose of worn-out parts [8]. }\end{array}$ \\
\hline Industrial ecology & $\begin{array}{c}\text { Industrial ecology deals with the interrelation and interdependence of material, } \\
\text { mainly industrial, production, human and other living organisms and their } \\
\text { environment, i.e. ecological and economic systems are the subject of industrial } \\
\text { ecology studies. The concept of industrial ecology is one of the approaches to } \\
\text { achieve higher levels of efficiency in the use of material and energy resources [9]. }\end{array}$ \\
\hline Environmental \\
economics & $\begin{array}{c}\text { Environmental economics is a field of science that is addressing the relationship } \\
\text { between ecosystems and economic systems in the widest sense. It brings together } \\
\text { ecological, anthropological, sociological and other sciences that are necessary to } \\
\text { interact with the economy if society aims to become sustainable [10]. }\end{array}$ \\
\hline
\end{tabular}

In terms of system analysis, the circular economy can be considered at the micro-level (products, companies, consumers), meso-level (regions, eco-industrial parks, production clusters) and macro-level (national economy, international level).

Moving to the circular economy is inevitably followed by active interdisciplinary interaction. First, the set tasks require the application of general scientific methods: deductive and inductive reasoning, analysis and synthesis, institutional analysis, statistical, comparative and cause and effect analysis, factor analysis, historical method, and other general theoretical methods. Secondly, the issue involves specific knowledge about environmental processes, which necessitates working with data of geo-ecological, hydrogeological, landscape and geochemical, engineering and geological surveys, analytical experimental works in laboratory and field conditions, use of physical and numerical modelling methods through GIS-technologies.

An essential condition for the implementation of the circular economy is that geographical, environmental, economic, social, historical factors and other specific features of particular territories should be taken into account. The diversity of territorial contexts leads to different needs and opportunities, which should be considered when implementing and evaluating the CE [11].

The systems of indicators for evaluating the circular economy have their specific features depending on the object level: micro-level, meso-level, or macro-level.

Given the objectives of this article, we note several studies devoted to assessing the CE at the meso-level. Y. Geng et al. (2012) suggested a system consisting of 12 indicators at the level of industrial parks and assessment of their impact on the ecosystem [12]. The paper of W. Su et al. (2013) presents two evaluation indicator systems. The first one belongs to the Ministry of Environmental Protection and contains 20 indicators divided into 4 groups: economic development, reducing and recycling of materials, pollution control, administration and management. The second one is an indicator system of the Commission for Development and Reforms; the system classifies 13 indicators divided into 4 groups: resource production rates, resource consumption rates, comprehensive resource management, and waste reduction [13]. The study of Pakhomova et al. (2017) presents the Circular Economy Development Index for Industries (CEDI), which takes into account the volume of technically processed products, the volume of reused products, the volume of recycled products, the volume of treated products and wastes, the weight factor of the applied method of waste and used products management for industrial sectors, the total volume of waste of industrial sectors and products out of service [14].

However, since the concept of the CE is being implemented, it is rather difficult at the moment to single out a system of assessment that would encourage the transition to the $\mathrm{CE}$ 
bearing in mind regional historical and economic specifics. We suggest looking at the CE assessment system from a different perspective, that is to say, the assessment should be based on the actual environmental problems and economic features of specific territories. In our opinion, such a system at the meso-level is necessary for ensuring a more practical impact on environmentally challenging industries in specific regions.

\section{Results and Discussion}

Being the basis of economic competitiveness, industrial regions (with a high share of the processing sector in the Gross Regional Product (GRP) structure) are becoming leaders in environmental system degradation. The CE offers exceptional opportunities for these areas.

The CE is focused on the optimization of industrial systems through the construction of a new model of the economic production system, establishing a new type of interaction between nature and society in the path of resource formation. It creates resource management methodological tools for the industrial system by integrating resource management processes [15].

Sverdlovsk region is a clear example of the environmental system degradation in an industrial region.

Table 2.Share of manufacturing industries in the GRP structure, $\%$

\begin{tabular}{|l|c|c|c|}
\hline \multicolumn{1}{|c|}{ Area } & $\mathbf{2 0 1 6}$ & $\mathbf{2 0 1 7}$ & $\mathbf{2 0 1 8}$ \\
\hline Russia & 16.9 & 17.4 & 18.1 \\
\hline Sverdlovsk region & 30.6 & 31.1 & 32.6 \\
\hline
\end{tabular}

The share of the manufacturing industry in the GRP structure of the region exceeds $30 \%$; this figure is almost twice as high as the total in Russia (Table 2).

The region is known for the development of ferrous and non-ferrous metallurgy, construction, chemical production and mining, including gold mining. Industrial development is closely followed by the introduction of technologies that contribute to ecosystem degradation. This underlines the targeted contradiction between the interests of business in making profits and the interests of society in achieving a better environment for life.

Major environmental issues related to industrial development in Sverdlovsk region:

- Increasing the negative impact on the environment caused by higher emissions of pollutants into the atmosphere, discharge of polluted wastewater, and waste generation and disposal due to increased industrial production;

- A significant number of industrial enterprises exceeds the maximum permissible impact limits (emissions, discharges), leading to a greater anthropogenic load on the environment;

- The low level of use and recycling of production and consumption waste, which leads to soil degradation, deterioration of natural landscape areas and contamination of surface water bodies and groundwater;

- The high energy and resource intensity of manufactured industrial products, which necessitates constant involvement of ever-increasing volumes of raw materials, water and energy [16]. 
Table 3. The impact of major economic activities on environmental pollution in Sverdlovsk region (based on 2017 data)

\begin{tabular}{|c|c|c|c|c|}
\hline \multirow{2}{*}{ Economic activity } & \multicolumn{3}{|c|}{ The share of activity in the total volume of pollution: } \\
\cline { 2 - 5 } & $\begin{array}{c}\text { emissions of } \\
\text { harmful } \\
\text { substances } \\
\text { into the } \\
\text { atmosphere }\end{array}$ & $\begin{array}{c}\text { polluted } \\
\text { wastewater } \\
\text { discharged to } \\
\text { surface } \\
\text { water bodies, } \\
\text { without treatment } \\
\text { or being } \\
\text { insufficiently } \\
\text { treated }\end{array}$ & $\begin{array}{c}\text { water } \\
\text { consu } \\
\text { mption }\end{array}$ & $\begin{array}{c}\text { generate } \\
\text { d waste }\end{array}$ \\
\hline Extraction of minerals & $15.8 \%$ & $9.8 \%$ & $8.6 \%$ & $86.2 \%$ \\
\hline Manufacturing industries & $27.6 \%$ & $30.9 \%$ & $35.2 \%$ & $8.5 \%$ \\
\hline $\begin{array}{c}\text { Supply of electricity, gas, } \\
\text { steam and air conditioning }\end{array}$ & $40.7 \%$ & $3.4 \%$ & $22.6 \%$ & $2.8 \%$ \\
\hline $\begin{array}{c}\text { Water supply, sewage, } \\
\text { waste collection and } \\
\text { disposal, elimination of } \\
\text { contaminants }\end{array}$ & $3.9 \%$ & $55.6 \%$ & $30.2 \%$ & $0.9 \%$ \\
\hline Other economic activities & $12.0 \%$ & $0.3 \%$ & $3.4 \%$ & $1.6 \%$ \\
\hline Total for Sverdlovsk region & $100.0 \%$ & $100.0 \%$ & $100.0 \%$ & $100.0 \%$ \\
\hline
\end{tabular}

The analysis of the structure of emissions by type of economic activity (see Table 3 ) shows that the mining sector accounts for about $16 \%$ of emissions of harmful substances into the air. Companies producing and distributing electricity, gas and water are responsible for the largest contribution to pollution - over $40 \%$. More than $27 \%$ of atmospheric emissions are generated by manufacturing facilities, in which emissions from the ferrous and non-ferrous metallurgy plants predominate.

Freshwater use for production needs and subsequent discharge of polluted wastewater play a significant role in the industry's environmental impact. Companies that are the most water-intensive by type of economic activity are those related to manufacturing industries (including metal and mechanical engineering as the main consumers of water resources) and to the production and distribution of electricity, gas and water. Representing more than $55 \%$, enterprises which produce and distribute electricity, gas and water predominate in the structure of discharge to surface water bodies of polluted wastewater without being treated or being insufficiently treated. The share of manufacturing industries is more than $30 \%$, among which are leading enterprises of metallurgical and chemical production.

Industrial waste is one of the most serious environmental pollution factors in Sverdlovsk region. Accumulated waste amounts to over 9.2 billion tons (as of the end of 2019). The bulk of industrial wastes comprises mining wastes (overburden and enclosing rocks), tailings and slags from metallurgical facilities, power plants' ash and sludge. In 2018, 154.9 million tons of industrial wastes were generated in Sverdlovsk region. Most of all industrial wastes - more than $80 \%$ - are generated in mining industries. The second position in terms of waste generation is occupied by manufacturing facilities, with ferrous and non-ferrous metal production wastes accounting for the major part. 
Manufacturing industries

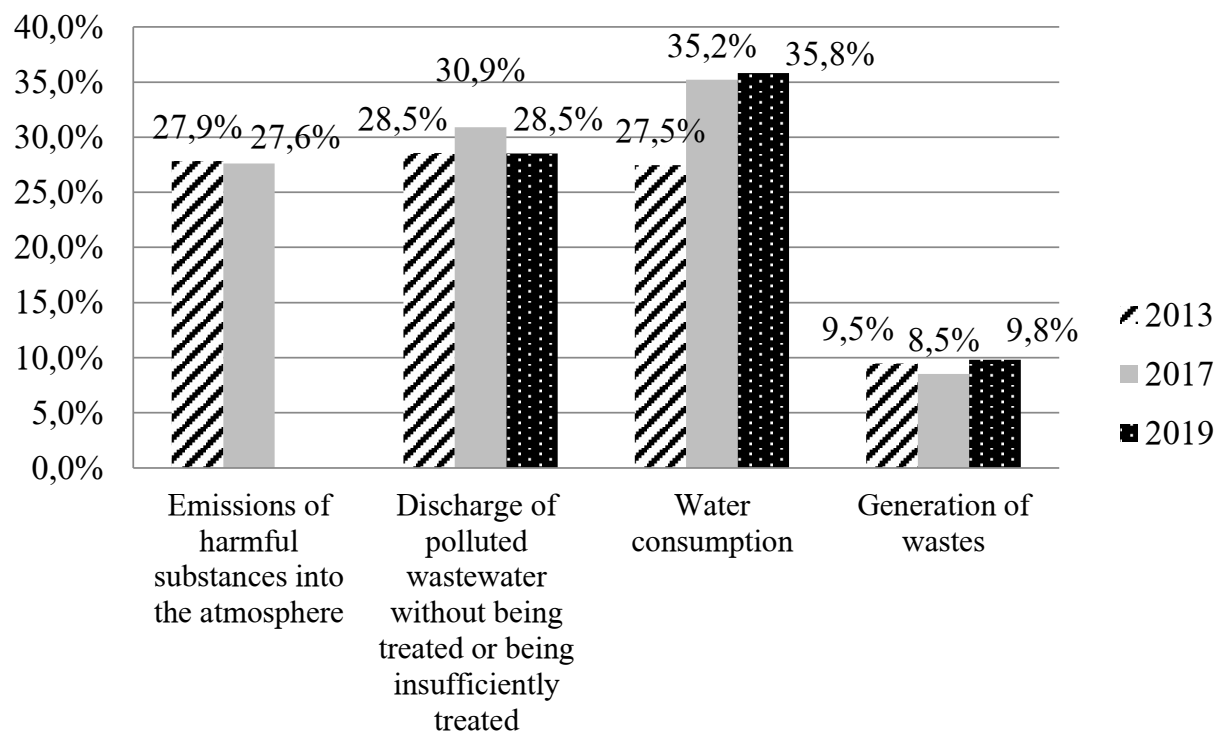

Fig. 1.Changes in the structure of industrial impact on environmental pollution in Sverdlovsk region

In terms of structure, the distribution of the negative environmental impact of manufacturing industries has not undergone significant changes in recent years (Fig.1), but in absolute terms, there is a positive trend in reducing the amount of all types of harm to the environment (Fig.2).

\section{Manufacturing industries}

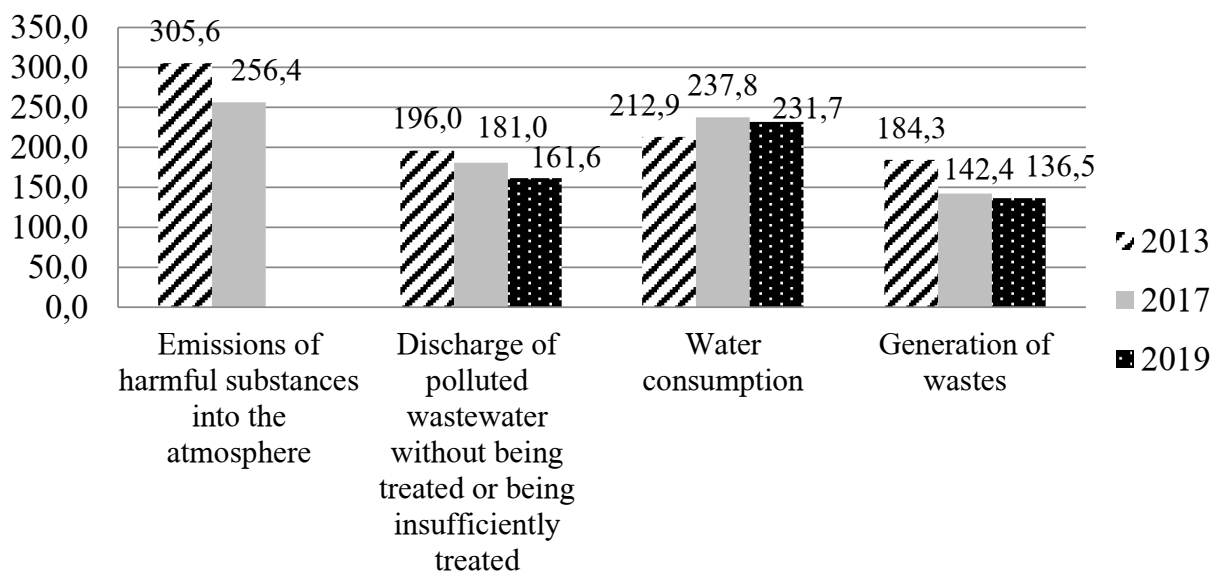

Fig. 2. Change of industrial impact on environmental pollution in Sverdlovsk region

The analysis of the impact of economic activities on environmental pollution in Sverdlovsk region has shown that manufacturing and mining industries are the main sources of nature's contamination in the region. The metallurgical industry imposes a significant burden on the ecosystem. Bearing in mind the revealed specifics, it is necessary 
to pay special attention to the potential practical implementation of circular economy principles in the mentioned sectors (Table 4).

Table 4.Potential ways to apply CE principles in Sverdlovsk region

\begin{tabular}{|c|c|}
\hline $\begin{array}{c}\text { Types of production and consumption } \\
\text { wastes in manufacturing and mining } \\
\text { industry }\end{array}$ & Waste management within the circular economy \\
\hline Ferrous metal mining wastes & $\begin{array}{ll}- & \text { Ballast material } \\
- & \text { Material for environmental remediation } \\
- & \text { As shale baffles } \\
- & \text { As construction materials } \\
- & \text { As additives for construction materials }\end{array}$ \\
\hline Non-ferrous metal mining wastes & $\begin{array}{ll}- & \text { Ballast material } \\
- & \text { Material for environmental remediation } \\
- & \text { As shale baffles } \\
- & \text { As construction materials } \\
- & \text { As additives for construction materials }\end{array}$ \\
\hline $\begin{array}{l}\text { Wastes of extraction of non-metallic } \\
\text { materials }\end{array}$ & $\begin{array}{ll}- & \text { As construction materials } \\
- & \text { As additives for construction materials } \\
- & \text { As shale baffles } \\
- & \text { Ballast material }\end{array}$ \\
\hline Wastes of energy feedstock extraction (coal) & $\begin{array}{ll}- & \text { Ballast material } \\
- & \text { Material for environmental remediation }\end{array}$ \\
\hline Enrichment rejects (tailings) & $\begin{array}{ll}- & \text { As mineral resources } \\
- & \text { As additives for construction materials } \\
- & \text { Material for environmental remediation }\end{array}$ \\
\hline $\begin{array}{l}\text { Wastes of metallurgical production (blast } \\
\text { furnace slags and steelmaking slags) }\end{array}$ & $\begin{array}{ll}- & \text { As mineral resources } \\
- & \text { As additives for construction materials } \\
- & \text { Material for environmental remediation } \\
- & \text { Ballast material }\end{array}$ \\
\hline $\begin{array}{c}\text { Wastes of water treatment and water } \\
\text { purification }\end{array}$ & $\begin{array}{ll}- & \text { Material for environmental remediation } \\
\text { - } & \text { As additives for fertilizers }\end{array}$ \\
\hline
\end{tabular}

Increasing ecological compatibility, resource and energy efficiency of the manufacturing facilities is one of the following tasks specified in the government program of Sverdlovsk region "Development of industry and science in Sverdlovsk region up to 2024". The top-priority goals of the region's scientific and technological development are to obtain scientific and technical results, create technologies that will form the basis for the innovative development of the domestic market of products and services, as well as provide a transition to an environmentally friendly and resource-saving industry. The development and implementation of new eco-friendly and cost-effective production technologies may contribute to increased investment in fixed assets, job creation and increased tax revenues at all levels of the national budget. However, the task set in the government program assumes only one target indicator: the number of industrial sector enterprises which implement projects aimed at introducing the best available technologies into industrial production [17].

In our opinion for more coordinated actions in the sphere of the CE development in the region, it is necessary to emphasize that at present there is no system of indicators that would allow assessing the contribution of enterprises to the circular economy development. Such a system would make it possible to assess, firstly, the effectiveness of pollution prevention and minimization measures taken by enterprises within the sector. And secondly, it would help regional authorities to stimulate environmentally responsible activities of industries and individual business entities.

We are offering to consider the following indicators of the circular economy development in the manufacturing sector: 


\section{Environmental}

1.1 Emissions of harmful substances into the atmosphere by enterprises belonging to a certain sector of the OKVED (Russian National Classifier of Types of Economic Activity) in the light of the contribution of this activity to the GRP structure.

1.2 Discharge of polluted wastewater (without being treated and being insufficiently treated) by enterprises belonging to a certain sector of the OKVED in the light of the contribution of this type of activity to the GRP structure.

1.3 The volume of natural water used by enterprises belonging to a certain sector of the OKVED in the light of the contribution of this type of activity to the GRP structure.

1.4 Generation of production waste by enterprises belonging a certain section of the OKVED in the light of the contribution of this type of activity to the GRP structure.

2. Administrative

1.5 Recycling indicators for specific types of waste (for Sverdlovsk region, Table 4).

2.1 The volume of "green" government purchases for the region.

2.2 The amount of investment in innovations aimed at environmental protection.

2.3 The number of patents related to innovative technologies applied in the circular economy.

Basing on the existing statistics, the use of indicators 1.1-1.4 allowed us to clearly demonstrate the dynamics of the negative impact on the ecosystem versus the economic performance of the industry (Table 5).

Table 5.Assessment of the impact of manufacturing industries on environmental pollution in Sverdlovsk region

\begin{tabular}{|l|l|l|l|l|}
\hline Period & $\begin{array}{l}\text { Emissions of } \\
\text { harmful } \\
\text { substances into } \\
\text { the atmosphere } \\
\text { kg per 1 } \\
\text { thousand rubles }\end{array}$ & $\begin{array}{l}\text { Discharge } \\
\text { of polluted wastewater } \\
\text { without being treated or } \\
\text { being } \\
\text { insufficiently treated, } \\
\text { cubic meters per 1 } \\
\text { thousand rubles }\end{array}$ & $\begin{array}{l}\text { Water use, } \\
\text { cubic meters } \\
\text { per 1 } \\
\text { thousand } \\
\text { rubles }\end{array}$ & $\begin{array}{l}\text { Generation } \\
\text { of waste, } \\
\text { kg per 1 } \\
\text { thousand } \\
\text { rubles }\end{array}$ \\
\hline 2017 & 0.39 & 0.27 & 0.36 & 21.52 \\
\hline 2018 & 0.32 & 0.23 & 0.31 & 19.04 \\
\hline
\end{tabular}

The system of indicators for assessing the circular economy, which is linked to the specific regional environmental concerns, enables local and regional authorities to focus on promoting the greening of industry.

\section{Conclusions}

The use of circular economy principles and tools is frequently seen as both a means of achieving sustainable development goals and a factor of economic competitiveness. This is explained by the fact that business activities within the context of the circular economy are aimed at keeping the cost of products, materials and resources as high as possible while minimising the amount of polluting emissions and waste generated. The CE offers special opportunities for industrial regions - being the basis for competitiveness they are leading in the environmental system degradation. At present, it is not easy to identify a system for assessing CE parameters that would take into account regional historical and economic specifics. In this regard, this study attempts to assess the CE against the actual environmental issues and economic realities of a particular region. Such a system of 
additional indicators merging environmental and economic information at the meso-level is vital for a focused impact on environmentally challenged industries.

\section{Acknowledgements}

The reported study was funded by RFBR, project number 20-010-00558.

\section{References}

1. J. Korhonen, A. Honkasalo, J. Seppälä, Ecological Economics, 143, 37 (2018)

2. J. Kirchherr, D. Reike, M. Hekkert, Resources, Conservation \& Recycling, 127, 221 (2017)

3. F. Silvestri, F. Spigarelli, M. Tassinari, Journal of Cleaner Production, 255 (2020)

4. The future we want, The Conference of United Nations on sustainable development RIO +20, https://rio20.un.org/sites/

5. Pauli Gyunter, The Blue Economy. 10 Years. 100 Innovations. 100 Million Jobs. Paradigm publications Taos, (2010)

6. Cora C., From green to blue economy,(2013) https://business.inquirer.net/

7. W.Mc Donough, M. Braungart, Cradle to Cradle: Remaking the Way We Make Things, 202 (2002)

8. M.M. Brutyan, M.P. Vahromeeva, T.M. Vorozhejkina, Problems of modern economy: monograph, 262 (2016)

9. O.YU. Ganyuhina, D.A. Agapov, Bulletin of KRAGSiU State and law,25 (2018)

10. Mateos Rodriges Avrora, Proceedings of the Saint Petersburg state University of Economics, 1(109), (2018)

11. M. Bačova, K. Böhme, M. Guitton, M.van Herwijnen, T. Kállay, J. Koutsomarkou, I. Magazzù, E.O' Loughlin, A. Rok, Pathways to a circular economy in cities and regions, https://urbact.eu/

12. Y. Geng, J. Fu, J. Sarkis, B. Xue, Journal of Cleaner Production, 23, 216 (2012)

13. B. Su, A. Heshmati, Y. Geng, X. Yu, Journal of Cleaner Production,42, 215 (2013)

14. N.V. Pakhomova, K.K. Richter, M.A. Vetrova, Bulletin of St. Petersburg State University,33 (2) (2017)

15. E. Mishenin, Marketing and innovation management,2, 329 (2017), https://www.researchgate.net/

16. The greening process of industrial production of Sverdlovsk region, http://gossmi.ru/

17. Development of industry and science in Sverdlovsk region up to 2024 , http://docs.cntd.ru/document/429009170 